\title{
PENERAPAN CLEARITY METER SEBAGAI ALAT UKUR SEDERHANA KUALITAS INFLUEN DAN EFLUEN PENGUJIAN PARAMETER TSS, TDS, COD, DAN BOD DI IPAL PALGADING DAN TIRTO ASRI
}

\author{
Widodo Brontowiyono ${ }^{1)}$, Elita Nurfitriyani Sulistyo ${ }^{1)}$, Suphia Rahmawati ${ }^{1)}$, Nurul \\ Istiqomah Agustin 1) \\ ${ }^{1)}$ Program Studi Teknik Lingkungan, Universitas Islam Indonesia, Yogyakarta \\ Email: elita@ uii.ac.id
}

\begin{abstract}
Abstrak
Daerah Istimewa Yogyakarta merupakan daerah dengan pertumbuhan penduduk yang tinggi. Hal ini mempengaruhi tingginya jumlah limbah domestik yang dihasilkan. IPAL Komunal dapat menjadi salah satu solusi dalam pengolahan air limbah domestik. Berdasarkan data dari DLH DIY 2016 tercatat 376 IPAL komunal di seluruh DIY, tetapi hanya 41 IPAL yang dipantau, dan sisanya tidak diketahui nilai efluen yang dihasilkan. Selain itu,tingginya biaya pengujian parameter juga menjadi alasan. Diperlukan suatu alternatif pemantauan yang mudah, murah, sederhana, portabel, dan hasil langsung dapat dibaca sehingga dapat dilakukan secara mandiri. Clearity meter merupakan suatu alat ukur sederhana yang digabungkan dengan kurva kalibrasi untuk mengetahui hubungan antar parameter dengan metode analisis regresi linier berganda. Penelitian dilakukan di IPAL komunal Palgading dan Tirto Asri dengan parameter uji TSS, TDS, COD, dan BOD dengan metode pada SNI 6989 tahun 2009 tentang Air dan Air Limbah. Tabung dengan diameter besar mempunyai hasil yang lebih baik dimana nilai $R^{2}$ dan signifikansinya mendekati ketetapan meskipun belum sesuai. Perlu dilakukan penelitian lebih lanjut agar memperlihatkan korelasi antar parameter dan kestabilan alat.
\end{abstract}

Kata kunci: Air Limbah Domestik, Clearity Meter, Pemantauan IPAL komunal

\begin{abstract}
Yogyakarta Special Region is an area with high population growth. This affects the high amount of domestic waste produced. Communal WWTP can be a solution in domestic wastewatertreatment. Data from DLH DIY 2016 recorded 376 communal WWTPs throughout DIY, but only 41 WWTPs were monitored, the rest did not know the value of the efluen generated. The high cost of parameter testing is also a reason. An alternative monitoring is needed that is easy, inexpensive, simple, portable, and the results can be read immediately so that it can be done independently. The clearity meter is a simple measuring instrument that is combined with a calibration curve to determine the relationship between parameters using the multiple linear regression analysis. The research was conducted at the Palgading and Tirto Asri communal WWTPs with the TSS, TDS, COD, and BOD test parameters relate in SNI 6989 year 2009 abut Water and Wastewater. Tubes with large dimensions have better results where the $R^{2}$ value and its significance are close to fixed although not yet suitable.
\end{abstract}

Keywords: Clearity Meter, Domestic Wastewater, Monitoring of Communal Wastewater Treatment

\section{PENDAHULUAN}

Air limbah domestik merupakan buangan yang berasal dari aktivitas sehari-hari yang berhubungan dengan pemakaian air, dapat berasal dari WC, kamar mandi, dapur, dan cucian (Permen LHK No.68 Tahun 2016). Jika air buangan tersebut langsung dibuang ke lingkungan 
tanpa adanya proses pengolahan terlebih dahulu dapat mengganggu keseimbangan fisika dan kimiawi air sehingga dapat mengalami pencemaran.

Salah satu pengendalian dari limbah domestik adalah dibangunnya sistem air limbah skala rumah tangga atau disebut IPAL komunal, dengan harapan kualitas efluen limbah domestik memenuhi baku mutu. Dalam pengelolaannya terdapat campur tangan masyarakat sehingga masyarakat dapat mandiri mengurusnya (Sofyan, 2016). Menurut Dinas Lingkungan Hidup (DLH) D.I.Yogyakarta pada tahun 2016 tercatat terdapat 376 IPAL komunal, dengan cakupan 30 hingga $300 \mathrm{KK}$ yang tersebar di Yogyakarta. Berdasarkan penelitian Bhakti dan Herumukti , 2016, dari 33 IPAL yang dijalankan di Surabaya, terdapat 13 unit IPAL yang dipantau, tetapi hanya 8 unit yang dipantau sesuai prosedur, yaitu pengujian kualitas setiap 6 bulan sekali. Begitupun dengan penelitian (Kurnianingtyas et al., 2020). suatu IPAL seharusnya dilakukan monitoring kualitasnya setiap 6 bulan sekali. Namun, fakta di lapangan menunjukkan adanya IPAL yang belum pernah dilakukan monitoring selama 9 tahun berjalannya IPAL. Kendala ini terjadi karena biaya operasional yang didapatkan dari iuran warga tidak berjalan dan juga harga pengujian yang cukup tinggi, sehingga dana untuk pengujian kualitas IPAL Komunal tidak tersedia.

Dari beberapa permasalahan tersebut diperlukan alternatif pemantauan kualitas IPAL yang mudah sehingga dapat dilakukan secara mandiri dan cepat oleh masyarakat. Salah satu alternatifnya adalah dengan alat clearity meter, suatu alat pengukuran sederhana yang digabungkan dengan kurva kalibrasi untuk mengetahui nilai beberapa parameter air limbah sekaligus. Hal ini merupakan salah satu bentuk pengabdian kepada masyarakat, sehingga diharapkan mempermudah pemantauan dan tidak membebani masyarakat dalam segi biaya, baik dalam pengoperasian ataupun perbaikan jika terjadi kerusakan. Clearity meter merupakan suatu alat yang diadopsi dari sistem johkasou dan secchi dimana mempunyai keuntungan harga yang murah, mudah, dan efektif. Penelitian ini dilakukan untuk menguji air limbah IPAL komunal dengan alat clearity meter ditinjau dari karakteristiknya berupa parameter BOD, COD, TSS, dan TDS dengan tujuan mengetahui kualitas IPAL komunal yang akan diteliti.

\section{METODE PENELITIAN}

\subsection{Waktu dan Lokasi}

Metode purposive digunakan sebagai metode penentuan lokasi IPAL komunal dan terpilih IPAL Komunal Palgading di RT 4 RW 18, Sinduharjo dan IPAL Komunal Tirto Asri di 
Dusun Sembung Jalan Besi Jangkang Km 1, Sukoharjo, Ngaglik, Sleman. Analisis sampel dan pengujian sampel dilakukan di Laboratorium Kualitas Air Teknik Lingkungan, Fakultas Teknik Sipil dan Perencanaan, Universitas Islam Indonesia (TL, FTSP, UII). Pengambilan dan pengujian sampel dilakukan pada bulan September hingga November 2020. Pengambilan dan pengujian sampel dilakukan saat pandemi Covid-19 berlangsung, dimana penggunaan air bersih meningkat dan saat pengambilan sampel telah mengikuti protokol kesehatan yang berlaku.

\subsection{Pengambilan dan Pengujian Sampel}

Pengambilan air sampel dilakukan setiap hari Rabu dan Kamis dengan waktu pengambilan pada pukul 8 pagi yang merupakan jam puncak pemakaian air, dengan menggunakan metode contoh sesaat pada bagian inlet dan outlet mengacu pada SNI 6989.59:2008. Pengujian sampel dan pembacaan alat clearity meter dilakukan duplo, dimana untuk pembacaan membutuhkan minimal 3 orang pembaca agar mendapatkan hasil yang lebih relevan dan meningkatkan ketepatan percobaan. Hal ini merupakan pendekatan statistik. Metode pengujian parameter dapat dilihat pada Tabel 1.

Tabel 1. Metode pengujian parameter

\begin{tabular}{lcc}
\hline Parameter & Pengujian & Metode \\
\hline TSS & SNI 06-6989.3-2004 & Gravimetri \\
\hline TDS & & Portable dengan TDS meter \\
\hline COD & SNI 6989.2:2009 & $\begin{array}{c}\text { Refluks tertutup secara } \\
\text { spektrofotometri }\end{array}$ \\
\hline BOD & SNI 6989.72:2009 & Titrasi secara iodometri \\
\hline
\end{tabular}

\subsection{Alat Clearity Meter}

Clearity meter (Gambar 1) menggunakan bahan akrilik dan mika, disangga menggunakan papan kayu agar lebih stabil. Alat ini mempunyai ketinggian hinga $136 \mathrm{~cm}$ dan terdapat 2 jenis diameter, yaitu $4 \mathrm{~cm}$ dan $2 \mathrm{~cm}$. Hal ini bertujuan untuk membandingkan keefektifan kedua diameter tersebut. Di sebelah tabung ditempelkan alat pengukur ketinggian air. Sedangkan di bawah tabung terdapat sebuah penutup berwarna hitam dan putih. Terdapat juga drain valve di bawah pipa sehingga memudahkan untuk menyesuaikan ketinggian air.

Setidaknya membutuhkan 2 orang untuk melakukan pengujian alat. Setelah dilakukan pemasangan tutup dan memastikan drain valve telah tertutup rapat, hal yang harus dilakukan pertama kali adalah menghomogenkan sampel air limbah. Orang pertama akan mulai memasukkan air ke dalam tabung secara perlahan dan memastikan jika secchi disk sudah tidak terlihat, maka penambahan air sudah harus dihentikan. Orang kedua akan langsung 
melakukan pembacaan ketinggian air. Jika air dalam tabung terlalu banyak, dapat dilakukan pembuangan air secara perlahan menggunakan drain valve. Setiap akan pergantian air sampel, tabung harus dibilas menggunakan air bersih terlebih dahulu untuk membersihkan kotoran yang tertinggal di dalam tabung karena sampel sebelumnya.

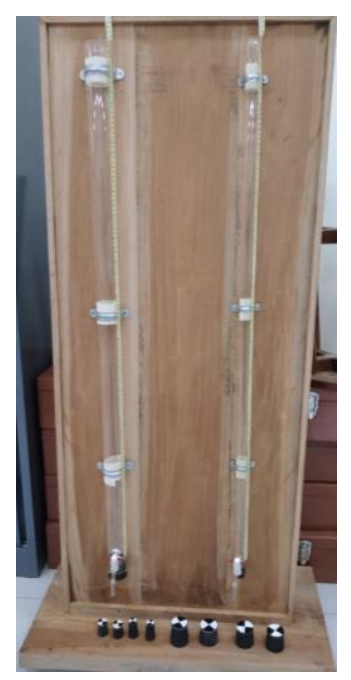

\section{Gambar 1. Alat clearity meter}

\subsection{Metode Analisis Data}

Analisis data dilakukan untuk mengetahui tingginya korelasi antar parameter TSS, TDS, COD, BOD, dan ketinggian dengan menggunakan metode regresi linier berganda. Dari sinilah dapat diketahui parameter mana saja yang relevan dan dapat digunakan. Sebelum dapat menggunakan regresi linier berganda perlu dilakukan pengujian asumsi-asumsi klasik. Uji asumsi klasik merupakan persyaratan yang harus dipenuhi pada analisis regresi linier berganda. Uji asumsi yang digunakan adalah uji normalitas, multikolinieritas, dan heteroskedesitas. Terpenuhinya asumsi klasik agar diperoleh model regresi dengan estimasi yang tidak bias dan pengujian dapat dipercaya. Salah satu tujuan pengujian asumsi klasik untuk mengetahui ada tidaknya multikolinearitas (Purnomo, 2017).

a. Uji normalitas

Uji normalitas bertujuan untuk menguji apakah dalam model regresi variabel pengganggu atau residual memiliki distribusi normal. Seperti diketahui bahwa uji t dan F mengasumsikan bahwa nilai residual mengikuti distribusi normal. Jika asumsi ini dilanggar maka uji statistik menjadi tidak valid untuk jumlah sampel kecil (Ghozali, 2013).

b. Uji multikolinieritas

Uji multikolinearitas adalah uji untuk melihat korelasi antar variabel bebas. Jika ditemukan variabel bebas yang mempunyai korelasi yang sangat kuat, maka secara logika persamaan 
regresinya cukup diwakili oleh salah satu variabel saja. Dapat dikatakan mempunyai korelasi sangat kuat ketika nilai $r>0,90$. Cara lain untuk mengetahui ada tidaknya multikolinearitas adalah dengan melihat nilai Variance Inflation Factor (VIF) dan Collinearity Tolerance. Jika nilai VIF $\leq 10$ dan Collinearity Tolerance $<0,1$, maka dapat dinyatakan tidak terjadi multikolinearitas (Yudiaatmaja, 2013).

c. Uji heteroskedesitas

Uji heteroskedastisitas bertujuan menguji apakah model regresi terjadi ketidaksamaan variance dari residual satu pengamatan ke pengamatan yng lain. Jika variance dari residual satu pengamatan ke pengamatan yang lain tetap, maka disebut Homoskedastisitas dan jika berbeda disebut Heteroskedastisitas. Model regresi yang baik adalah yang Homoskesdastisitas atau tidak terjadi Heteroskesdastisitas. Kebanyakan data crossection mengandung situasi heteroskesdastisitas karena data ini menghimpun data yang mewakili berbagai ukuruan (Ghozali, 2013).

Setelah poin di atas telah terpenuhi maka dapat dilanjutkan ke regresi linier berganda. Regresi linier berganda merupakan model persamaan yang menjelaskan hubungan satu variabel tak bebas (Y) dengan dua atau lebih variabel bebas $\left(\mathrm{X}_{1}, \mathrm{X}_{2} \ldots \mathrm{X}_{\mathrm{n}}\right)$. Tujuannya adalah untuk memprediksi nilai variabel tak bebas (Y) apabila nilai-nilai variabel bebasnya $\left(\mathrm{X}_{1}, \mathrm{X}_{2} \ldots \mathrm{X}_{\mathrm{n}}\right)$ diketahui. Di samping itu juga untuk mengetahui arah hubungan variabel tak bebas dengan variabel-variabel bebasnya. Persamaan 1 berikut merupakan regresi linier berganda secara matematik.

$$
\mathrm{Y}=\mathrm{a}+\mathrm{b}_{1} \mathrm{X}_{1}+\mathrm{b}_{2} \mathrm{X}_{2}+\ldots+\mathrm{bn} \mathrm{Xn}
$$

Kondisi-kondisi bila koefisien-koefisien regresi, yaitu $b_{1}$ dan $b_{2}$ mempunyai nilai:

- Nilai $=0$, dalam hal ini variabel $\mathrm{Y}$ tidak dipengaruhi oleh $\mathrm{X}_{1}$ dan $\mathrm{X}_{2}$

- Nilainya negatif, terjadi hubungan dengan arah terbalik antara variabel tak bebas Y dengan variabel-variabel $\mathrm{X}_{1}$ dan $\mathrm{X}_{2}$

- Nilainya positif, terjadi hubungan searah antara variabel tak bebas Y dengan variabel bebas $\mathrm{X}_{1}$ dan $\mathrm{X}_{2}$

Koefisien-koefisien regresi $b_{1}$ dan $b_{2=}$ serta konstanta a dapat dihitung dengan persamaan 2, 3 dan 4.

$\mathbf{a}=\frac{\sum \mathbf{Y}-\left(\mathbf{b}_{1} \times \sum \mathrm{x}_{1}\right)-\left(\mathbf{b}_{2} \times \sum \mathrm{x}_{2}\right)}{\mathbf{n}}$ 


$$
\begin{aligned}
& b_{1}=\frac{\left.\llbracket\left(\sum x_{2}^{2} x \sum x_{1} Y\right)-\left(\sum x_{2} Y x \sum x_{1} X_{2}\right)\right]}{\left.\llbracket\left(\sum x_{1}^{2} x \sum x_{2}^{2}\right)-\left(\sum x_{1} x X_{2}\right)^{2}\right]} \\
& b_{2}=\frac{\left.\llbracket\left(\sum x_{1}^{2} x \sum x_{2} Y\right)-\left(\sum x_{1} Y x \sum x_{1} X_{2}\right)\right]}{\left.\llbracket\left(\sum x_{1}^{2} x \sum x_{2}^{2}\right)-\left(\sum x_{1} x X_{2}\right)^{2}\right]}
\end{aligned}
$$

Selanjutnya dilakukan perhitungan koefisien korelasi ganda (r), hal ini berfungsi mengetahui seberapa besar korelasi yang terjadi antar variabel-variabel $\mathrm{X}_{1}, \mathrm{X}_{2}, \ldots, \mathrm{X}_{\mathrm{n}}$ secara serentak dengan variabel Y. Besarnya nilai koefisien korelasi ganda dapat dihitung dengan persamaan 5 .

$$
\mathbf{r}=\sqrt{\mathbf{r}^{2}}=\sqrt{\frac{\left(\mathrm{b}_{1} \sum \mathbf{x}_{1} \mathbf{y}\right)+\left(\mathrm{b}_{2} \sum \mathbf{x}_{2} y\right)}{\sum \mathbf{y}^{2}}}
$$

Metode korelasi mempunyai standar sebagai berikut:

- $<0,20 \quad$ : dapat dianggap tidak ada hubungan

- 0,20-0,40 : hubungan rendah

- $0,41-0,70$ : hubungan cukup

- $0,71-0,90$ : hubungan kuat

- $0,91-1,00$ : hubungan sangat kuat

Nilai $\mathrm{r}:-1 \leq \mathrm{r} \leq+1$. Semakin mendekati nilai +1 atau -1 , maka semakin kuat korelasi yang terjadi dan jika $\mathrm{r}$ mendekati 0, maka semakin lemah korelasi yang terjadi (Yuliara, 2016). Dari nilai data yang didapatkan, maka diketahui korelasi dari setiap parameter. Dapat diambil kesimpulan parameter mana saja yang relevan dan dapat digunakan.

\section{HASIL DAN PEMBAHASAN}

\subsection{Gambaran Umum IPAL Komunal}

Lokasi IPAL yang digunakan adalah Palgading dan Tirto Asri. Dapat dilihat deskripsi singkat dari kedua IPAL yang akan dikaji pada penelitian ini (Tabel 2).

Tabel 2. Kondisi IPAL Palgading

\begin{tabular}{llcc}
\hline No. & \multicolumn{1}{c}{ Kriteria } & IPAL Palgading & IPAL Tirto Asri \\
\hline 1. & Lokasi & $\begin{array}{c}\text { RT 4 RW 18, Sinduharjo, } \\
\text { Ngaglik Sleman }\end{array}$ & $\begin{array}{c}\text { Dusun Sembung Jalan Besi Jangkang Km } \\
\text { 1, Sukoharjo, Ngaglik, Sleman }\end{array}$ \\
\hline 2. & Pendiri & KPP Gading Sehat & KSM Tirto Asri \\
\hline 3. & Tahun berdiri & 2012 & 2016 \\
\hline 4. & Kapasitas maksimum & 100 & 120 \\
\hline 5. & Kapasitas saat ini & 60 & 100 \\
\hline 6. & Teknologi & $A B R$ & $A B R+$ Anaerobic filter \\
\hline 8. & Pengurasan & 4 kali selama berdirinya IPAL & 2 tahun sekali \\
\hline 9. & Permasalahan & Efluen berbau dan berbusa & - \\
\hline
\end{tabular}




\subsection{Kualitas Air Limbah Domestik}

Kualitas air dapat diketahui dari beberapa parameter pada air limbah, baik yang belum mengalami pengolahan ataupun hasil dari pengolahan. Air limbah domestik mempunyai karakteristik yang menunjukan ciri dari kualitas air limbah yang ditinjau. Pengambilan sampel dilakukan pada bulan September yang masuk musim kemarau pada pukul 8 pagi. Hasil yang didapatkan akan lebih tinggi jika diambil pada musim hujan, hal ini terjadi karena ketika musim hujan limpasan air hujan semakin tinggi dan dapat bercampur dengan sampel sehingga mempengaruhi konsentrasi parameter. Jam 8 pagi juga merupakan jam puncak pemakaian air bersih sehingga air limbah yang dihasilkan dan konsentrasinya akan lebih tinggi jika dibandingkan pada jam lainnya. Pada penelitian ini, kualitas air limbah domestik dibandingkan dengan Peraturan Daerah Istimewa Yogyakarta Nomor 7 Tahun 2016.

\section{a. Total Suspended Solid (TSS)}

TSS merupakan jumlah berat zat tersuspensi dalam volume tertentu di dalam air yang dinyatakan dengan mg/L. Kadar TSS berbanding lurus dengan proses degradasi, yaitu semakin kecil penurunan nilai TSS pada pengolahan limbah, menunjukkan proses degradasi bahan organik juga semakin kecil (Paramita, 2012). Hasil pengujian kadar TSS IPAL komunal Palgading dan Tirto Asri pada bagian inlet dan outlet dapat dilihat pada Gambar 2.

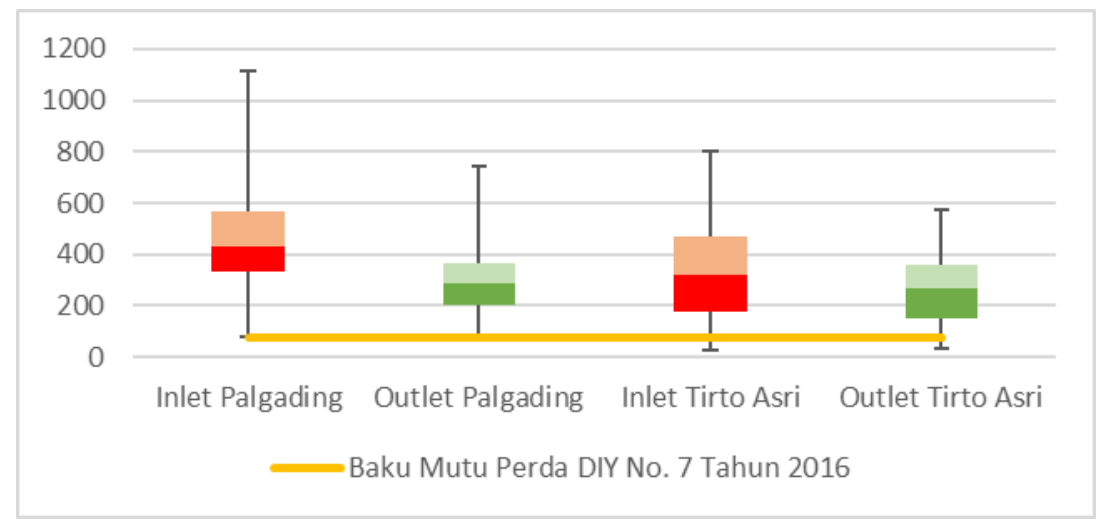

Gambar 2. Diagram boxplot TSS IPAL komunal

Nilai TSS hasil pengujian inlet IPAL Palgading berada pada kisaran $80-1.112 \mathrm{mg} / \mathrm{L}$ dan pada bagian outlet berkisar $80-742 \mathrm{mg} / \mathrm{L}$. Sedangkan inlet IPAL Tirto Asri, nilai TSS berkisar $24-800 \mathrm{mg} / \mathrm{L}$ dan pada bagian oultlet berkisar $32-572 \mathrm{mg} / \mathrm{L}$. IPAL Palgading dan Tirto Asri mempunyai nilai efisiensi penurunan kadar TSS rata-rata hingga 43\%. Kadar TSS yang telah didapat dibandingkan dengan standar baku mutu Perda DIY No. 7 Tahun 2016. Dapat diketahui bahwa semua titik pengambilan sampel tidak ada yang memenuhi baku mutu. 
Kadar TSS yang masih melebihi baku mutu dapat dipengaruhi dari tingginya kadar TSS pada bagian inlet. Namun, jika dilihat dari nilai efisiensi removal yang sangat rendah dapat disebabkan kurangnya perawatan berupa pengurasan lumpur yang merupakan bentuk pemeliharaan terhadap kinerja IPAL, perbandingan antara black water dan grey water yang masuk ke dalam IPAL sehingga mempengaruhi kadar TSS, dan sampah yang masuk sehingga dapat menyebabkan penyumbatan. Saat observasi di lapangan, pada IPAL Palgading tidak ditemukan barscreen sehingga sampah dapat langsung masuk ke unit-unit pengolahan.

\section{b. Total Dissolved Solid (TDS)}

Padatan tersuspensi berkorelasi positif dengan kekeruhan. Kekeruhan pada perairan tergenang layaknya danau lebih banyak disebabkan oleh bahan-bahan koloid dan pertikelpartikel halus. Sedangkan kekeruhan pada sungai yang sedang banjir dapat disebabkan oleh bahan-bahan tersuspensi yang berukuran lebih besar berupa lapisan permukaan tanah yang terbawa oleh air hujan (Effendi, 2003). Hasil pengujian kadar TDS IPAL komunal Palgading dan Tirto Asri pada bagian inlet dan outlet dapat dilihat pada Gambar 3.

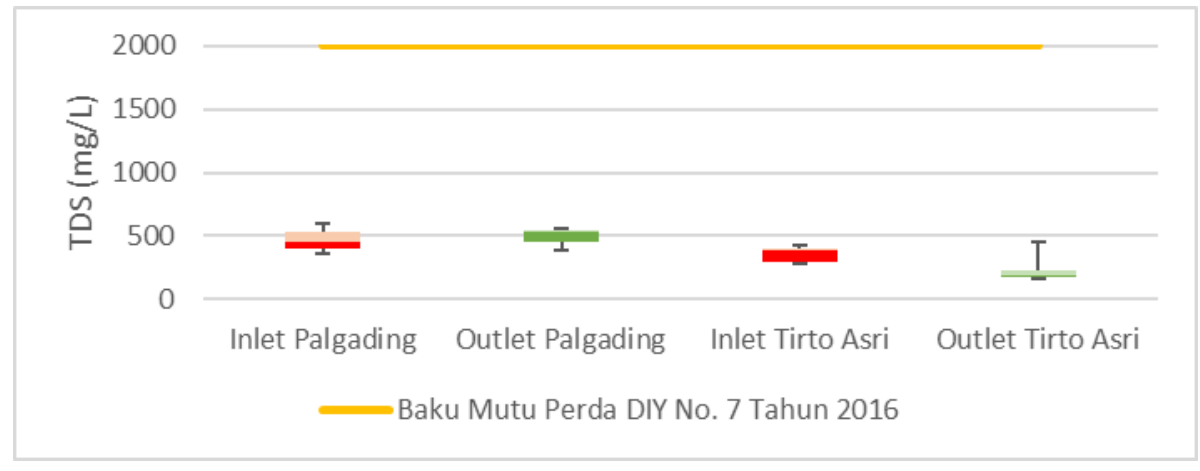

Gambar 3. Diagram boxplot TDS IPAL komunal

Nilai TDS hasil pengujian pada inlet IPAL Palgading berkisar 362,5 - $598 \mathrm{mg} / \mathrm{L}$ dan pada bagian outlet berkisar 392 - $562 \mathrm{mg} / \mathrm{L}$. Untuk nilai TDS bagian inlet IPAL Tirto Asri berkisar 277,5 - 425,5 mg/L dan pada bagian outlet berkisar $174-453,5 \mathrm{mg} / \mathrm{L}$.

Sebagian besar kadar TDS pada bagian outlet IPAL Palgading lebih besar dari pada inlet. Sedangkan untuk IPAL Tirto Asri mempunyai nilai efisiensi penurunan hingga 57\%. Dapat dikatakan dalam mengolah kadar TDS belum maksimal pada kedua IPAL. Pada Error! Reference source not found. dapat dilihat bahwa semua nilai standar deviasi lebih kecil dari pada nilai mean, sehingga data yang dihasilkan dikatakan baik. Kadar TDS yang telah 
didapat dibandingkan dengan standar baku mutu Perda DIY No. 7 Tahun 2016. Bagian outlet maupun inlet kedua IPAL telah memenuhi baku mutu.

Outlet IPAL Palgading mempunyai nilai yang lebih besar dari pada inlet. Dapat ditemui kumpulan busa pada bagian outlet yang dapat mempengaruhi kadar TDS. Tingginya nilai TDS dapat disebabkan oleh sisa bahan-bahan anorganik dan molekul dari sisa air buangan, seperti deterjen, surfaktan yang larut dalam air dan molekul sabun (Kustiyaningsih dam Irawanto, 2020).

\section{c. Chemical Oxygen Demand (COD)}

COD menunjukkan jumlah oksigen yang diperlukan untuk dekomposisi secara kimiawi. Kandungan COD yang tinggi dapat mempengaruhi kandungan oksigen terlarut dalam air menjadi rendah bahkan habis (South \& Nazir, 2016). Jika dibandingkan dengan kadar BOD, kadar COD umumnya lebih besar karena senyawa yang dioksidasi secara kimiawi lebih banyak daripada biologis. COD merupakan parameter utama dalam air limbah, kandungan COD akan mempengaruhi jumlah pencemaran zat organik yang dapat dioksidasi secara alamiah melalui proses mikrobiologi dan mengakibatkan kurangnya jumlah oksigen terlarut dalam suatu perairan (Wijayaningrat, 2018). Hasil pengujian kadar COD IPAL komunal Palgading dan Tirto Asri pada bagian inlet dan outlet dapat dilihat pada Gambar 4.

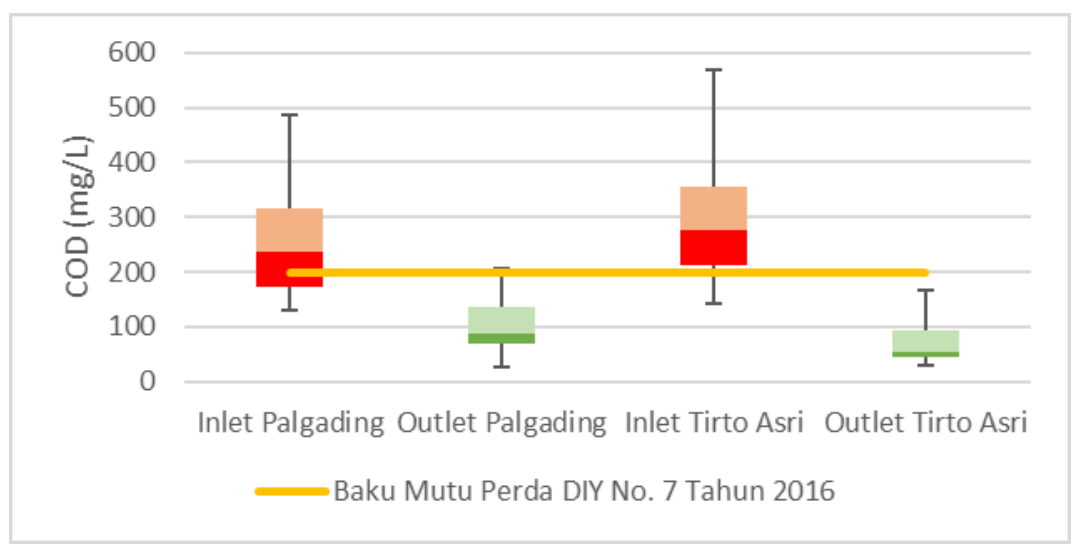

Gambar 4. Diagram boxplot COD IPAL komunal

Nilai COD hasil pengujian pada inlet IPAL Palgading berkisar 130 - 487,5 mg/L dan pada bagian outlet berkisar 27,5 - $205 \mathrm{mg} / \mathrm{L}$. Sedangkan untuk nilai COD bagian inlet IPAL Tirto Asri berkisar 143,75 - 568,75 mg/L dan pada bagian outlet berkisar 28,75 - 167,5 mg/L. IPAL Palgading mempunyai efisiensi penurunan kadar COD rata-rata hingga 58\% dan IPAL Tirto Asri mempunyai nilai efisiensi penurunan rata-rat hingga 75\%. Kadar COD yang telah 
didapat dibandingkan dengan standar baku mutu Perda DIY No. 7 Tahun 2016. Bagian inlet untuk kedua IPAL terdapat nilai yang telah memenuhi baku mutu dan untuk bagian outlet kedua IPAL telah memenuhi baku mutu.

Pipa outlet IPAL Palgading berada di bawah permukaan air sungai, sehingga dapat menyebabkan masuknya air sungai ke dalam pipa outlet. Air sungai yang masuk akan bercampur dengan efluen dan dapat mempengaruhi tingginya kadar COD (Purwatiningrum, 2016).Penurunan kadar COD juga dipengaruhi oleh waktu tinggal. Semakin besar penyisihan maka semakin lama waktu tinggalnya. Mikrooganisme yang terdapat di dalam IPAL komunal mengalami siklus hidup dan dapat mengalami kejenuhan hingga kematian. Hal ini menyebabkan materi organik tidak terurai dengan optimal ditandai dengan tingginya atau meningkatnya kadar COD (Susanti, et al., 2018).

\section{d. Biochemical Oxygen Demand (BOD)}

BOD merupakan jumlah oksigen yang dibutuhkan mikroorganisme aerobik untuk menguraikan bahan organik karbon selama 5 hari. Pengujian kadar BOD menggunakan metode titrasi iodometri. Sampel yang bersifat oksidator akan direduksi oleh kalium iodida berlebih dan akan menghasilkan iodium. Iodium selanjutnya dititrasi dengan larutan baku natrium tiosulfat, banyaknya natrium tiosulfat sebagai titran setara dengan iodium yang dihasilkan (Sutisna, 2018). Hasil pengujian kadar BOD IPAL komunal Palgading dan Tirto Asri pada bagian inlet dan outlet dapat dilihat pada Gambar 5.

Nilai BOD hasil pengujian pada inlet IPAL Palgading berkisar 16,65 - 79,45 mg/L dan pada bagian outlet berkisar 1,97 - 7,02 mg/L. Sedangkan untuk nilai BOD bagian inlet IPAL Tirto Asri berkisar 6,37 - 45,01 mg/L dan pada bagian outlet berkisar 0,77 - 20,38 mg/L. IPAL Palgading mempunyai efisiensi penurunan kadar BOD rata-rata hingga 90\% dan IPAL Tirto Asri mempunyai nilai efisiensi penurunan rata-rat hingga 74\%. Kadar BOD yang telah didapat dibandingkan dengan standar baku mutu Perda DIY No. 7 Tahun 2016. Bagian outlet maupun inlet baik IPAL Palgading dan Tirto Asri telah memenuhi baku mutu.

Penurunan kadar BOD dipengaruhi oleh besarnya debit air limbah, semakin kecil maka penurunan BOD semakin besar (Susanti, et al., 2018). Parameter BOD berkaitan dengan proses self-purification badan air, yaitu kemampuan alami air dalam membersihkan diri. Semakin besar kadar BOD maka semakin besar pula zat organik yang harus diuraikan, hal ini menunjukkan semakin tingginya pencemaran yang terjadi (Arifudin \& Setiyono, 2019). 
Pengukuran BOD juga berfungsi untuk perkembangan mendesain pengolahan biologis bagi air limbah tersebut (Purwatiningrum, 2016).

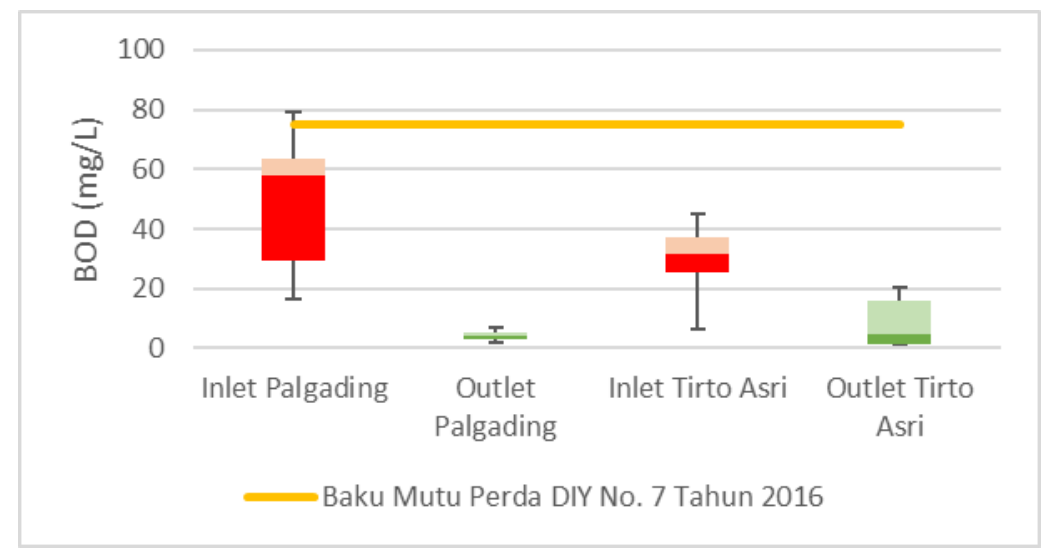

Gambar 5. Diagram boxplot BOD IPAL komunal

\subsection{Analisis Data}

Dalam penggunaan alat clearity meter, semakin keruh sampel yang digunakan maka ketinggian air akan semakin rendah. Hal ini disebabkan dari nampaknya secchi disk yang berada di bawah. Semakin keruh sampel maka kadar TDS dan TSS akan semakin tinggi, tetapi mereka tidak berhubungan karena mengukur padatan yang berbeda. TSS yang dapat menurunkan intensitas cahaya yang masuk ke suatu perairan dapat berdampak berkurangnya kadar oksigen sehingga dapat meningkatkan kadar COD dan BOD. COD merupakan parameter utama dalam air limbah. Dimana kandungan BOD terhitung dalam COD, sehingga kadar COD pasti lebih tinggi dari BOD.

Pada penelitian ini alat clearity meter terdiri dari dua tabung yang mempunyai ukuran yang berbeda. Hal pertama yang dilakukan adalah apakah tabung dengan ukuran besar dan kecil mempunyai tingkat keefektifan yang sama atau tidak. Jika sama dan memenuhi beberapa aspek maka akan terbentuk empat regresi sedangkan jika tidak sama maka akan terbentuk delapan regresi yang berbeda.

\subsubsection{Perbandingan Diameter Kecil dan Besar}

Tahap kali ini akan membuktikan sebuah hipotisis untuk mengetahui apakah tabung dengan diameter besar dan kecil mempunyai tingkat signifikansi yang sama. Jika ternyata sama maka dalam penggunaanya dapat dipilih salah satu. Terbentuklah hipotesis:

$\mathrm{H}_{0}=$ Diameter besar dan kecil berbeda seignifikansi

$\mathrm{H}_{1}=$ Diameter besar dan kecil signifikansi sama 
Dari Tabel 3 menunjukkan antara diameter besar dan diameter kecil meskipun dengan sampel air limbah yang sama mempunyai nilai signifikansi yang berbeda. Hal ini menandakan tingkat efisiensi kedua diameter memiliki nilai yang berbeda. Sehingga hipotesis $\mathrm{H}_{0}$ diterima dan $\mathrm{H}_{1}$ ditolak.

Tabel 3. Signifikansi setiap sampel dan diameter tabung

\begin{tabular}{|c|c|c|c|c|}
\hline \multirow{8}{*}{ 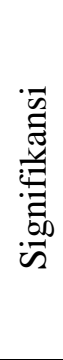 } & \multirow{4}{*}{$\begin{array}{c}\text { IPAL } \\
\text { Palgading }\end{array}$} & \multirow{2}{*}{ Inlet } & Diameter Besar & 0,046 \\
\hline & & & Diameter Kecil & 0,197 \\
\hline & & \multirow{2}{*}{ Outlet } & Diameter Besar & 0,836 \\
\hline & & & Diameter Kecil & 0,856 \\
\hline & \multirow{4}{*}{$\begin{array}{c}\text { IPAL } \\
\text { Tirto Asri }\end{array}$} & \multirow{2}{*}{ Inlet } & Diameter Besar & 0,082 \\
\hline & & & Diameter Kecil & 0,816 \\
\hline & & \multirow{2}{*}{ Outlet } & Diameter Besar & 0,586 \\
\hline & & & Diameter Kecil & 0,362 \\
\hline
\end{tabular}

\subsubsection{Analisis Masing-Masing Sampel}

\section{a. Inlet IPAL Palgading diameter besar}

Data inlet IPAL Palgading diameter besar dapat dilihat pada Tabel 4.

Tabel 4. Data inlet IPAL Palgading diameter besar

\begin{tabular}{ccccc}
\hline $\begin{array}{c}\mathrm{H} \\
(\mathrm{cm})\end{array}$ & $\begin{array}{c}\text { TDS } \\
(\mathrm{mg} / \mathrm{L})\end{array}$ & $\begin{array}{c}\text { TSS } \\
(\mathrm{mg} / \mathrm{L})\end{array}$ & $\begin{array}{c}\text { COD } \\
(\mathrm{mg} / \mathrm{L})\end{array}$ & $\begin{array}{c}\text { BOD } \\
(\mathrm{mg} / \mathrm{L})\end{array}$ \\
\hline 6 & 436 & 604 & 487,5 & 79,45 \\
\hline 7 & 364 & 328 & 172,5 & 25,44 \\
\hline 7,5 & 555 & 268 & 280 & 16,65 \\
\hline 8,5 & 406,5 & 468 & 427,5 & 59,22 \\
\hline 9 & 519,5 & 396 & 237,5 & 57,84 \\
\hline 10,75 & 435,5 & 466 & 207,5 & 69,47 \\
\hline 12,5 & 362,5 & 220 & 171,25 & 53,37 \\
\hline 14,5 & 376 & 44 & 150 & 26,64 \\
\hline
\end{tabular}

Pada pengujian distibusi normal, seluruh parameter telah memenuhi distribusi normal. Untuk pengujian korelasi sederhana terjadi korelasi yang kuat antara parameter TSS dengan ketinggian sebesar $-0,730$ atau $73 \%$. Sedangkan parameter yang lain dapat dikatakan tidak terjadi korelasi dengan ketinggian. Terlihat pula terjadi korelasi yang kuat antara TSS dengan COD sebesar 0,757 atau 75,7\% dan dengan BOD sebesar 0,762 atau 76,2\% dan tidak terjadi 
multikolinearitas. Sedangkan untuk korelasi berganda yang memenuhi signifikansi, F hitung, dan $\mathrm{T}$ hitung adalah ketinggian, TSS, dan BOD, sehingga didapatkan persamaan Tinggi = 12,068 - 0,024TSS + 0,122BOD.

\section{b. Inlet IPAL Palgading diameter kecil}

Data inlet IPAL Palgading diameter kecil dapat dilihat pada Tabel 5. Pada pengujian distibusi normal, seluruh parameter telah memenuhi distribusi normal. Untuk pengujian korelasi sederhana terjadi korelasi yang kuat antara parameter TDS dengan ketinggian sebesar $-0,811$ atau $81,1 \%$. Sedangkan parameter yang lain dapat dikatakan tidak terjadi korelasi dengan ketinggian. Terlihat pula terjadi korelasi yang kuat antara TSS dengan BOD sebesar 0,744 atau $74,4 \%$ dan tidak terjadi multikolinearitas. Sedangkan untuk korelasi berganda tidak ada yang memenuhi aspek signifikansi, nilai $\mathrm{T}$ hitung dan $\mathrm{F}$ hitung. Didapatkan persamaan regresi ketinggian dengan TDS, yaitu Tinggi $=22,832-0,027$ TDS.

Tabel 5. Data inlet IPAL Palgading diameter kecil

\begin{tabular}{ccccc}
\hline $\begin{array}{c}\mathrm{H} \\
(\mathrm{cm})\end{array}$ & $\begin{array}{c}\text { TDS } \\
(\mathrm{mg} / \mathrm{L})\end{array}$ & $\begin{array}{c}\text { TSS } \\
(\mathrm{mg} / \mathrm{L})\end{array}$ & $\begin{array}{c}\text { COD } \\
(\mathrm{mg} / \mathrm{L})\end{array}$ & $\begin{array}{c}\mathrm{BOD} \\
(\mathrm{mg} / \mathrm{L})\end{array}$ \\
\hline $\mathbf{8}$ & 555 & 268 & 280 & 16,65 \\
\hline $\mathbf{8 , 2 5}$ & 519,5 & 396 & 237,5 & 57,84 \\
\hline $\mathbf{9 , 5}$ & 406,5 & 468 & 427,5 & 59,22 \\
\hline $\mathbf{1 1}$ & 436 & 604 & 487,5 & 79,45 \\
\hline $\mathbf{1 1 , 5}$ & 462 & 520 & 271,25 & 59,80 \\
\hline $\mathbf{1 1 , 7 5}$ & 435,5 & 466 & 207,5 & 69,47 \\
\hline $\mathbf{1 2}$ & 364 & 328 & 172,5 & 25,44 \\
\hline $\mathbf{1 5}$ & 362,5 & 220 & 171,25 & 53,37 \\
\hline
\end{tabular}

\section{c. Outlet IPAL Palgading diameter besar}

Data outlet IPAL Palgading diameter besar dapat dilihat pada Tabel 6. Pada pengujian distribusi normal, awalnya ketinggian belum berdistribusi normal, setelah dilakukan transformasi data, seluruh parameter telah memenuhi distribusi normal. Untuk pengujian korelasi terjadi korelasi yang kuat antara ketinggian dengan TDS sebesar -0,779 atau 77,9\% dan TSS sebesar $-0,709$ atau 70,9\%. Terlihat pula adanya korelasi yang kuat antara TDS dengan TSS sebesar $-0,821$ atau 82,1\%, TDS dengan BOD sebesar $-0,784$ atau 78,4\%, dan TSS dengan BOD sebesar 0,749 atau 74,9\% dan seluruh korelasi berganda, tetapi tidak ditemukan terjadinya multikolinearitas. Meskipun begitu terdapat aspek-aspek yang tidak terpenuhi seperti, signifikansi, T hitung, dan F hitung. Begitu juga dengan korelasi sederhana, 
meskipun terjadi korelasi TDS dengan ketinggian serta TSS dengan ketinggian. Namun tetap tidak memenuhi aspek tersebut.

Tabel 6. Data outlet IPAL Palgading diameter besar

\begin{tabular}{ccccc}
\hline $\begin{array}{c}\mathrm{H} \\
(\mathrm{cm})\end{array}$ & $\begin{array}{c}\mathrm{TDS} \\
(\mathrm{mg} / \mathrm{L})\end{array}$ & $\begin{array}{c}\text { TSS } \\
(\mathrm{mg} / \mathrm{L})\end{array}$ & $\begin{array}{c}\mathrm{COD} \\
(\mathrm{mg} / \mathrm{L})\end{array}$ & $\begin{array}{c}\text { BOD } \\
(\mathrm{mg} / \mathrm{L})\end{array}$ \\
\hline $\mathbf{1 4}$ & 455,5 & 742 & 57,5 & 6,66 \\
\hline $\mathbf{1 7 , 5}$ & 523 & 376 & 137,5 & 2,39 \\
\hline $\mathbf{1 8}$ & 483,5 & 318 & 133,75 & 5,53 \\
\hline $\mathbf{1 9}$ & 554 & 216 & 77,5 & 3,98 \\
\hline $\mathbf{2 0 , 7 5}$ & 536 & 192 & 75 & 4,01 \\
\hline $\mathbf{2 1 , 5}$ & 533 & 80 & 27,5 & 1,58 \\
\hline $\mathbf{4 2 , 8}$ & 558 & 208 & 30 & 2,39 \\
\hline
\end{tabular}

\section{d. Outlet IPAL Palgading diameter kecil}

Data outlet IPAL Palgading diameter kecil dapat dilihat pada Tabel 7. Pada pengujian distribusi normal, awalnya ketinggian, TDS, dan TSS belum berdistribusi normal. Setelah dilakukan transformasi data, TSS masih belum memenuhi 0,05 sehingga tidak dapat dilakukan pengujian ke tahap selanjutnya karena data tidak normal.

Tabel 7. Data outlet IPAL Palgading diameter kecil

\begin{tabular}{ccccc}
\hline $\begin{array}{c}\mathrm{H} \\
(\mathrm{cm})\end{array}$ & $\begin{array}{c}\text { TDS } \\
(\mathrm{mg} / \mathrm{L})\end{array}$ & $\begin{array}{c}\text { TSS } \\
(\mathrm{mg} / \mathrm{L})\end{array}$ & $\begin{array}{c}\text { COD } \\
(\mathrm{mg} / \mathrm{L})\end{array}$ & $\begin{array}{c}\text { BOD } \\
(\mathrm{mg} / \mathrm{L})\end{array}$ \\
\hline $\mathbf{1 4}$ & 455,5 & 742 & 57,5 & 6,66 \\
\hline $\mathbf{1 5 , 5}$ & 545 & 328 & 205 & 4,76 \\
\hline $\mathbf{1 6}$ & 554 & 216 & 77,5 & 3,98 \\
\hline $\mathbf{1 8}$ & 533 & 80 & 27,5 & 1,58 \\
\hline $\mathbf{1 9}$ & 536 & 192 & 75 & 4,01 \\
\hline $\mathbf{1 9 , 5}$ & 438,5 & 200 & 95 & 3,91 \\
\hline $\mathbf{2 0 , 7 5}$ & 483,5 & 318 & 133,75 & 5,53 \\
\hline $\mathbf{3 9 , 5}$ & 558 & 208 & 30 & 2,39 \\
\hline
\end{tabular}

\section{e. Inlet IPAL Tirto Asri diameter besar}

Data inlet IPAL Tirto Asri diameter besar dapat dilihat pada Tabel 8. Pada pengujian distibusi normal, seluruh parameter telah memenuhi distribusi normal. Untuk pengujian korelasi sederhana maupun bertingkat tidak terjadi korelasi yang kuat antara ketinggian dengan semua parameter independen. Tetapi terlihat adanya korelasi yang kuat antara TDS dengan COD sebesar 0,791 atau 79,1\%, antara parameter independen dengan seluruh parameter dependen dengan nilai 0,719 atau $71,9 \%$ dan tidak ditemukan terjadinya 
multikolinearitas. Namun, hal ini tidak dapat dilanjutkan ke regresi karena nilai signifikansi tidak memenuhi dimana seharusnya $\mathrm{p}<0,05$.

Tabel 8. Data inlet IPAL Tirto Asri diameter besar

\begin{tabular}{ccccc}
\hline $\begin{array}{c}\mathrm{H} \\
(\mathrm{cm})\end{array}$ & $\begin{array}{c}\text { TDS } \\
(\mathrm{mg} / \mathrm{L})\end{array}$ & $\begin{array}{c}\text { TSS } \\
(\mathrm{mg} / \mathrm{L})\end{array}$ & $\begin{array}{c}\text { COD } \\
(\mathrm{mg} / \mathrm{L})\end{array}$ & $\begin{array}{c}\text { BOD } \\
(\mathrm{mg} / \mathrm{L})\end{array}$ \\
\hline $\mathbf{5 , 5}$ & 425,5 & 468 & 568,75 & 37,82 \\
\hline $\mathbf{7}$ & 398 & 420 & 390 & 31,80 \\
\hline $\mathbf{8}$ & 355 & 800 & 321,25 & 29,38 \\
\hline $\mathbf{8 , 7 5}$ & 392 & 226 & 285 & 45,01 \\
\hline $\mathbf{9}$ & 284 & 164 & 47,5 & 6,37 \\
\hline $\mathbf{1 0}$ & 280 & 224 & 167,5 & 28,59 \\
\hline $\mathbf{1 0 , 5}$ & 277,5 & 276 & 221,25 & 37,69 \\
\hline $\mathbf{1 2 , 5}$ & 403 & 24 & 275 & 21,87 \\
\hline $\mathbf{1 3 , 7 5}$ & 305,5 & 466 & 143,75 & 37,23 \\
\hline $\mathbf{1 5 , 5}$ & 402 & 8 & 272,5 & 22,61 \\
\hline & & & &
\end{tabular}

\section{f. Inlet IPAL Tirto Asri diameter kecil}

Data inlet IPAL Tirto Asri diameter kecil dapat dilihat pada Tabel 9. Pada pengujian distibusi normal, seluruh parameter telah memenuhi distribusi normal. Untuk pengujian korelasi sederhana maupun bertingkat tidak terjadi korelasi yang kuat antara ketinggian dengan semua parameter independen. Tetapi terlihat adanya korelasi yang kuat antara TDS dengan COD sebesar 0,764 atau 76,4\% dan tidak ditemukan terjadinya multikolinearitas. Meskipun begitu tidak dapat dilakukan pengujian ke tahap regresi jika dilihat dari signifikansi yang tidak memenuhi.

Tabel 9. Data inlet IPAL Tirto Asri diameter kecil

\begin{tabular}{ccccc}
\hline $\begin{array}{c}\mathrm{H} \\
(\mathrm{cm})\end{array}$ & $\begin{array}{c}\mathrm{TDS} \\
(\mathrm{mg} / \mathrm{L})\end{array}$ & $\begin{array}{c}\mathrm{TSS} \\
(\mathrm{mg} / \mathrm{L})\end{array}$ & $\begin{array}{c}\mathrm{COD} \\
(\mathrm{mg} / \mathrm{L})\end{array}$ & $\begin{array}{c}\text { BOD } \\
(\mathrm{mg} / \mathrm{L})\end{array}$ \\
\hline $\mathbf{7 , 5}$ & 355 & 800 & 321,25 & 29,38 \\
\hline $\mathbf{8 , 2 5}$ & 392 & 226 & 285 & 45,01 \\
\hline $\mathbf{8 , 7 5}$ & 416,5 & 122 & 477,5 & 35,26 \\
\hline $\mathbf{9}$ & 402 & 8 & 272,5 & 22,61 \\
\hline $\mathbf{9 , 5}$ & 277,5 & 276 & 221,25 & 37,69 \\
\hline $\mathbf{1 0}$ & 284 & 164 & 47,5 & 6,37 \\
\hline $\mathbf{1 1}$ & 398 & 420 & 390 & 31,80 \\
\hline $\mathbf{1 3}$ & 280 & 224 & 167,5 & 28,59 \\
\hline $\mathbf{1 4}$ & 378 & 24 & 202,5 & 22,24 \\
\hline
\end{tabular}




\section{g. Outlet IPAL Tirto Asri diameter besar}

Data outlet IPAL Tirto Asri diameter besar dapat dilihat pada Tabel 10. Pada pengujian distribusi normal, awalnya TDS belum berdistribusi normal. Setelah dilakukan transformasi data, TDS masih belum berdistribusi normal sehingga tidak dapat dilakukan pengujian ke tahap selanjutnya karena data tidak normal.

Tabel 10. Data outlet IPAL Tirto Asri diameter besar

\begin{tabular}{ccccc}
\hline $\begin{array}{c}\mathrm{H} \\
(\mathrm{cm})\end{array}$ & $\begin{array}{c}\text { TDS } \\
(\mathrm{mg} / \mathrm{L})\end{array}$ & $\begin{array}{c}\text { TSS } \\
(\mathrm{mg} / \mathrm{L})\end{array}$ & $\begin{array}{c}\mathrm{COD} \\
(\mathrm{mg} / \mathrm{L})\end{array}$ & $\begin{array}{c}\text { BOD } \\
(\mathrm{mg} / \mathrm{L})\end{array}$ \\
\hline $\mathbf{1 3}$ & 453,5 & 572 & 95 & 11,89 \\
\hline $\mathbf{5 2 , 7 5}$ & 237 & 192 & 53,75 & 19,96 \\
\hline $\mathbf{6 8}$ & 174 & 112 & 167,5 & 4,78 \\
\hline $\mathbf{7 1}$ & 218 & 452 & 28,75 & 20,38 \\
\hline $\mathbf{8 7 , 5}$ & 213 & 360 & 51,25 & 15,86 \\
\hline $\mathbf{9 9 , 5}$ & 205 & 32 & 65 & 2,38 \\
\hline $\mathbf{1 4 0}$ & 178,5 & 136 & 30 & 16,45 \\
\hline
\end{tabular}

\section{h. Outlet IPAL Tirto Asri diameter kecil}

Data outlet IPAL Tirto Asri diameter kecil dapat dilihat pada Tabel 11.

Tabel 11. Data outlet IPAL Tirto Asri diameter kecil

\begin{tabular}{ccccc}
\hline $\begin{array}{c}\mathrm{H} \\
(\mathrm{cm})\end{array}$ & $\begin{array}{c}\text { TDS } \\
(\mathrm{mg} / \mathrm{L})\end{array}$ & $\begin{array}{c}\text { TSS } \\
(\mathrm{mg} / \mathrm{L})\end{array}$ & $\begin{array}{c}\mathrm{COD} \\
(\mathrm{mg} / \mathrm{L})\end{array}$ & $\begin{array}{c}\mathrm{BOD} \\
(\mathrm{mg} / \mathrm{L})\end{array}$ \\
\hline $\mathbf{1 3 , 2 5}$ & 453,50 & 572,00 & 95,00 & 11,89 \\
\hline $\mathbf{4 2 , 5 0}$ & 237,00 & 192,00 & 53,75 & 19,96 \\
\hline $\mathbf{5 9 , 7 5}$ & 218,00 & 452,00 & 28,75 & 20,38 \\
\hline $\mathbf{6 7 , 5 0}$ & 174,00 & 112,00 & 167,50 & 4,78 \\
\hline $\mathbf{7 5 , 5 0}$ & 205,00 & 32,00 & 65,00 & 2,38 \\
\hline $\mathbf{8 4 , 5 0}$ & 213,00 & 360,00 & 51,25 & 15,86 \\
\hline $\mathbf{1 0 2 , 7 5}$ & 178,50 & 136,00 & 30,00 & 16,45 \\
\hline
\end{tabular}

Pada pengujian distribusi normal, awalnya TDS belum berdistribusi normal. Setelah dilakukan transformasi data, TDS masih belum berdistribusi normal sehingga tidak dapat dilakukan pengujian ke tahap selanjutnya karena data tidak normal. Secara keseluruhan korelasi berganda hanya terbentuk pada inlet IPAL Palgading diameter besar antara parameter TSS, BOD, dan ketinggian. Terbentuk pula regresi sederhana pada inlet IPAL Palgading diameter kecil parameter TDS dengan ketinggian. Tidak meratanya hasil korelasi yang terbentuk dapat terjadi karena beberapa faktor, seperti konsistensi air limbah setiap harinya yang tidak sama dan kurang homogennya larutan sampel. Dapat juga dilihat pada 
hasil pengujian parameter independen dan ketinggian air yang mempunyai fluktuasi cukup tinggi.

\section{KESIMPULAN}

Kualitas influen IPAL komunal Palgading dan Tirto Asri parameter TSS dan COD masih melebihi baku mutu, sedangkan parameter TDS dan BOD telah memenuhi baku mutu. Untuk bagian efluennya, parameter TDS, COD, dan BOD telah memenuhi baku mutu, sedangkan TSS masih melebihi baku mutu. Baku mutu yang digunakan berdasarkan Perda DIY No. 7 Tahun 2016.Pembuatan alat clearity meter perlu dilakukan pengembangan lebih lanjut. Karena hasil yang didapatkan belum maksimal. Meskipun begitu telah terbentuk regresi berganda pada inlet IPAL Palgading diameter besar antara parameter TSS, BOD, dan ketinggian sehingga terbentuk persamaan Y (ketinggian) $=12,068-0,024 \mathrm{TSS}+0,122 \mathrm{BOD}$. Terbentuk pula regresi sederhana pada inlet IPAL Palgading diameter kecil anatara parameter TDS dan ketinggian sehingga membentuk persamaan Y (ketinggian) $=22,832-0,027$ TDS. Sedangkan pada poin yang lain masih belum memenuhi dari segi normalitas dan signifikansinya.

\section{UCAPAN TERIMAKASIH}

Ucapan terima kasih ditujukan kepada Direktorat Penelitian dan Pengabdian Masyarakat (DPPM UII) yang telah memberikan hibah dengan no 07/Dir/DPPM/80/Batch 2/XI/2019.

\section{DAFTAR PUSTAKA}

Arifudin dan Setiyono. (2019). Evaluasi Instalasi Pengolahan Air Limbah (IPAL) Gedung Perkantoran X di Jakarta. JRL, 12 (2) : 89-98.

Bhakti, A dan Herumurti, W. (2016). Evaluasi Kinerja IPAL-IPAL Program SPBM-USRI Tahun Pembangunan 2012-2014 di Surabaya. Jurnal Teknik ITS, 5(2) : C118-C123.

Effendi, H. (2003). Telaah Kualitas Air: Bagi Pengelolaan Sumber Daya dan Lingkungan. Yogyakarta: Kanisius.

Kurnianingtyas, E., Prasetya, A., dan Tawfiequrrahman, A. (2020). Kajian Kinerja Sistem Instalasi Pengolahan Air LImbah (IPAL) Komunal (Studi Kasus: IPAL Komunal Kalisong, Kelurahan Sembung, Kecamatan Tulungagung, Kabupaten Tulungagung, Jawa Timur). Media Ilmiah Teknik Lingkungan, 5(1) : 62-70.

Kustiyaningsih dan Irawanto. (2020). Pengukuran Total Dissolved Solid (TDS) dalam Fitoremediasi Deterjen dengan Tumbuhan Sagittaria lancifolia. Jurnal Tanah dan Sumberdaya Lahan, 7(1) : 143-148. 
Paramita. (2012). BIodegradasi Limbah Organik Pasar dengan Menggunakan Mikroorganisme Alami Tangki Septik. Jurnal Sains dan Seni ITS , 1 : E23-E26.

Purwatiningrum, O. (2016). Gambaran Instalasi Pengolahan Air Limbah DOmestik Komunal di Kelurahan Simokerto, Kecamatan Simokerto, Kota Surabaya. Jurnal Kesehatan Lingkugan, 10 (2) :241-251.

Iskandar, S., Fransisca, I., Arianto, E., dan Ruslan, A. (2016). Buku 3 : Sistem Pengelolaan Air Limbah Domestik-Terpusat Skala Pemukiman. Jakarta: Kemetrian Pekerjaan Umum dan Perumahan Rakyat.

South dan Nazir. (2016). Karakteristik Air Limbah Rumah Tangga (Grey Water) pada Salah Satu Perumahan Menengah Keatas yang Berada di Tangerang Selatan. Ecolab, 10(2) : 47-102.

Susanthi, Purwanto, dan Suprihatin. (2018). Evaluasi Pengolahan Air Limbah Domestik dengan IPAL Komunal di Kota Bogor. Jurnal Teknologi Lingkungan, 19(2) : 229-238.

Sutisna, A. (2018). Penentuan Angka Dissolved Oxygen (DO) pada Air Sumur Warga Sekitar Industri CV. Bumi Waras Bandar Lampung. Jurnal Analis Farmasi, 3(4) : 246-251.

Wijayaningrat, A. T. (2018). Evaluasi Kinerja IPAL Komunal di Kecamatan Banguntapan dan Bantul, Kabupaten Bantul, D.I. Yogyakarta Ditinjau dari Parameter Fisika dan Kimia. Skripsi Program Studi Teknik Lingkungan Fakultas Teknik Sipil dan Perencanaan: Universitas Islam Indonesia.

Yuliara, I. M. (2016). Regresi Linier Berganda. Denpasar: Universitas Udayana. 